for example, the comb, serpent, crescent, and radiated sundisc, are also found on the early Christian monuments of Scotland, and seem to point to direct communication between Scotland and western Europe about 700 A.D. A sculptured stone from $\mathrm{Tu}$, in Jaederen, with 'a runic inscription of the peculiar character found on the Norwegian crosses in the Isle of Man, possibly points to an influence from that island.

On non-European archæology four papers were presented. $\mathrm{Mr}$. C. T. Currelly, in a sequence of Egyptian stone implements, considered that the development of the Thebaid palæoliths could be traced from the depth of the patina and from the scratchings. The Neolithic implements of the Thebaid, on the other hand, show little patination, though the length of the Neolithic period may be traced from the fact that unpatinated neoliths have been made by re-working patinated ones.

The Rev. W. A. Adams, in a paper on some ancient stone implement sites in South Africa, recorded the discovery of implements of Palæolithic type from five districts, the hill slope near Bosman's Crossing. Stellenbosch, the Karoo and the Vaal River terraces, near Kimberley, the Rhodesian uplands near Bulawayo, and the headlands of the Victoria Falls.

An interesting paper on prehistoric archæology in Japan was presented by Dr. Gordon Munro, in which considerable light was thrown on the question of the immigrations to the country from the mainland. Many Japanese archæologists deny the fact that the primitive inhabitants of Japan were of the same stock as the existing Ainu, but the discovery of Ainu remains in the shell-heaps proves that this people played a part in the Neolithic culture, and the excavations have revealed a connection between the pottery of this phase and that of the iron culture which accompanied the agricultural invaders from Asia. The progress of these invaders towards the east and north was slow, and may have begun about five centuries B.C., or even earlier. No undoubted Palæolithic remains were found, but the resemblance of the culture to that of other lands agrees with the general verdict of prehistoric intercommunication.

Finally, the Rev. Dr. Bryce, of Winnipeg, read a paper on the mound builders of North America, which was of peculiar interest in view of the association meeting in Winnipeg next year. An examination of a large number of these mounds led the author to conclude that they were built by the Toltecs, and that they mark the course of a Toltec immigration from the south along the Mississippi and Ohio to the Great Lakes and the St. Lawrence; along the Missouri ; and along the Mississippi proper to the Rainy and Red rivers. This would make the earliest mound date from about IIOO A.D.

In conclusion, it should be mentioned that the success which attended the meeting was in a very great measure due to the kindness and energy of $\mathrm{Mr}$. Laurence Steele, the section's local secretary.

\section{LOCAL SCIENTIFIC SOCIETIES AT THE BRITISH ASSOCIATION.}

DURING the Dublin meeting of the British Association the conference of delegates held two meetings under the chairmanship of Prof. H. A. Miers, F.R.S. At the opening meeting, held on September 3, the chairman read an address on the educational opportunities of local scientific societies. In this he reviewed the growth of such bodies, some of which dated back nearly a hundred years. In these cases they did pioneer work, and helped to create a general scientific atmosphere. With the birth of the British Association, which, he said, might be regarded as a magnified society of the same character changing its yearly habitat, a great stimulus was supplied, as at that time scientific work was supplemented in a very inadequate manner by the publishers and the Press. After this date the growth of local scientific societies and cheap elementary text-books, which stimulated a desire for sound knowledge, was very rapid. Gradually, however, the early manuals, containing perhaps a whole science, have been supplanted by the educational text-book used in schools and the specialist treatise for the advanced student. Thus the amateur nowadays is almost in danger of being placed in the position of his predecessor of sixty-five years ago. $\mathrm{He}$ has no time to go through a course of special reading in text-books of various grades, and without that, although perhaps quite learned in one branch of science, can get no adequate insight into modern advances through needless technicalities and their expression in a language which he cannot understand.

The same is the case with the greater scientific societies - they are becoming every day more highly specialised, both in their publications and in their membership. Here is the opening for the local scientific society, but only if it really attempts to meet the wants of the intelligent amateur. It is all very well to make arrangements for sections to take up the local flora and fauna, but what is wanted in addition is some common ground by which all the members can be united by their general interest in science, combined with some educational help to those to whom science is chiefly a hobby and a relaxation. One of the most useful functions of a body like a local society is to encourage a habit of expressing scientific result in simple and intelligible language that will appeal to the whole society. Indeed, nothing can be better or more useful for the scientific specialist himself than to attempt to explain his own work in simple language to a mixed audience. The set lecture is not so much needed, but the description by a speaker of what he has done or seen himself. In a local society no better material for educational improvement should exist where the members have joined it voluntarily, and, in the first instance, because they really wished to learn. In addition to this nothing is more wanted at the present day than books giving simple, untechnical accounts of the living work by the worker himself, and this should be done, not only in the newest fields of science, the popularisation of which is liable to be overdone, but in the more ordinary work of everyday science, which results in discoveries perhaps equally momentous, but at present buried beyond the reach of the amateur.

The educational work that the local societies can best perform through its members, who, though not children, have unprepared minds, is the encouragement of original research. This could be done, first, by inviting the trained and experienced workers to make known to them, through the medium of untechnical language, the beauty and interest of scientific work in the course of its progress, and of scientific discovery in the making; and, secondly, by providing them with followers who will continue to prosecute under their guidance original observation and even experimental research. Enthusiasm has been instilled and sincere students produced by the university extension movements; let the local societies initiate a new science extension movement by which the barrier between the professional man of science and the amateur, between the expert and the layman, will be broken down.

After discussion and votes of thanks, Sir Edward Brabrook proposed that "the conference desires to represent to the committee of recommendations that whenever a committee of the British Association enters upon a local investigation, notice should be given to any local scientific or archæological society so as to enable that society to offer any cooperation that may be desirable." This, having been seconded by the Rev. J. O. Bevan, was carried unanimously.

Mrs. Mary Hobson then read a paper on sanctuaries for our native flora and fauna, in which she discussed various schemes for obtaining, or getting public bodies to set aside, waste land as sanctuaries, instancing that in Ireland already such places existed as Lambay Island, protected by the Hon. Cecil Baring; at Glencar, co. Sligo, on land owned by the Wynne family; at Knocknarae Glen, in the same county, where the hartstongue ferns have the longest fronds in Britain, upwards of a yard in length; and, finally, at Clonbrock Forest, in Galway, where Lord Clonbrock has a sanctuary which has been undisturbed since Elizabethan times. She also animadverted especially on the destructive spirit of collecting rare birds and chance migrants, not to speak of other things. That was not the way to advance knowledge, which was, however, fostered by the study of birds in their native haunts. 
In the discussion on this paper several delegates took part. Mr. W. M. Webb, of the Selborne Society, gave some particulars about a sanctuary in which his society was interested. He also agreed that private collecting, if done at all, should be started with the idea of benefiting the many instead of the few. Mr. William Gray, of the Belfast Naturalists' Field Club, spoke as to the destruction by collectors of the eggs of rare birds, which would breed if they were not disturbed, and how last season the club, through providing a watcher, had been successful in the case of a previously much harried species. Mr. J. Hopkinson mentioned that public bodies sometimes were gross offenders in their demands for large numbers of some rare plant from a local habitat, while the Rev. Ashington Bullen spoke as to the scarcity or extinction in certain haunts of species that were formerly plentiful Mr. Harold Wager thought that the local societies could do much by encouraging a more scientific attitude towards collecting and by inducing a study of the habits and lifehistories of the living organism in the field.

The second meeting of the conference of delegates was held on September 8, and was presided over, in the absence of Prof. Miers, by Prof. Grenville A. J. Cole, vice-chairman. At this meeting Prof. G. H. Carpenter introduced the subject of detailed natural-history surveys of restricted areas, an important work suitable for local societies. In his remarks he described the researches lately carried out into the natural history of the island of Lambay, off the coast of co. Dublin, and what was being done at the present time on the North Bull, a grass-covered sandbank in Dublin Bay, known to be less than a century old. Prof. Carpenter urged the importance of the study of such restricted areas as likely to help in the solution of many geographical problems. Several delegates having spoken, Mr. Frederick Long, of the Norfolk and Norwich Naturalists' Society, directed attention to the fact that a few years ago Mr. Robert Gurney established a small laboratory on Sutton Broad, in Norfolk, for the use of anyone wishing to prosecute research worl in that area.

Mr. Henry Davcy then read his paper on the advisa bility of re-stocking haunts whence fauna and flora have disappeared. His main contention was that in the case of many of the rarer Lepidoptera, with which alone he ivas thoroughly ixmiliar, their disappearance or extinction was not so much due to man, but to natural causes, the reason of which in most cases had not yet been discovered. $\mathrm{He}$ instanced the case of the large copper, which disappeared in one locality through man, but in the other from no such cause, although he mentioned that a great fen-fire had been blamed. As for the growing rarity of many species, he thought that much destruction was caused by the ease with which the present-day collector was able to get about, but, speaking of the large blueLycaena arion-which had been killed off in most of its localities, he said that while collectors had caused its extinction at Barnwe!l Wold, its favourite habitat, it had also disnmenred from another resort in Northamptonshire to which the public had no access. Of this insect also he mentioned Mr. Frohawk's discovery in 1903, at its breeding ground in Cornwall, of the caterpillars living on thyme growing on or near ant hills, into which the full-grown larvæ descended so that the ants might remove a secretion which seemed deleterious to their health. As to restocking, he considered that it was of little value in the present state of our knowledge. The swallow-tailed butterflv. which in England is now restricted to a small area in the fens, from his observation on the Continent seemed to flourish among or near wooded hills, and never in the flats. However, no success resulted from the attempt to establish it on a large scale in the Peak of Derbyshire and in Devonshire.

Again, an insect which may be far from rare, in certain spots favours such a small area that it may be measured bv vards, notablv a locality in Sussex, where the marbled white is extremelv common in a tract about eighty vards square. Again, in the case of the clouded yellows, in some years the two species may be exceedingly abundant: in the intermediate time not a specimen is to be seen. In such a case re-stocking would be of no use, while the dis.appearance of the insects has not been caused by man.
Finally, Mr. Davey considered that, on the whole, the experiment of re-stocking former haunts was worth the attempt, although from what he had mentioned success was not assured. Such work ought to be undertaken, however, in a scientific spirit, and exact records should be kept. It was also highly desirable that the re-stocking should be tried in two places at the same time a few miles apart, and that individuals should be brought from different localities to avoid, so far as possible, the danger of inbreeding.

Prof. Carpenter during the discussion directed attention to the fact that the species that tended to become extinct were those of commercial value, while Prof. Cole thought that stocking localities with species that had not previously lived there would nullify much of the work on their natural distribution. Under the head of the introduction of insects to localities where they had become extinct or were becoming scarce, Mr. W. P. Stebbing directed attention to what was being done by Mr. Henry Preston, of Grantham. He had collected a large number of the caterpillars of the Peacock butterfly from clumps of nettles, which were always destroyed by the farmers before the insects were full grown, had kept them until they turned into chrysalises, and then on emerging as perfect insects had turned them loose in seemingly suitable spots.

Arising out of the previous papers, the Rev. J. O. Bevan brought forward the following resolution:- "That this Conference of Delegates of Corresponding Societies affirms the desirability of bringing under the notice of local societies the necessity for preserving the fauna and flora of their respective districts as against wanton destruction or careless and needless collecting." This was seconded by Mrs. Hobson, and carried unanimously.

At the close of the meeting Mr. F. A. Bellamy (Ashmolean Natural History Society of Oxfordshire), who had had his notes printed as a paper for distribution to the meeting, exhibited his method for the permanent recording of natural history or other observations by means of the card-catalogue system. In explaining the value to workers of such a catalogue, he said that care was needed when outlining such a scheme so that it would retain its usefulness whatever the size. $\mathrm{He}$ also gave an estimate of the cost of one unit (tray, cards, and cover) of the catalogue.

\section{UNIVERSITY AND EDUCATIONAL INTELLIGENCE.}

CAMbridge.-At the annual general meeting of the Philosophical Society, held on October 26, Prof. Sedgwick was elected president of the society.

It is proposed to confer the degree of Master of Arts, honoris causa, upon Prof. W. J. Pope, F.R.S., professor of chemistry, and upon Mr. K. J. J. Mackenzie, lecturer in agriculture.

Mr. R. C. Punnett has been appointed demonstrator of animal morphology for the year ending Michaelmas, I909, and Mr. F. H. Potts demonstrator of comparative anatomy.

London.-Prof. E. A. Minchin will represent the University at the Darwin centenary celebration at Cambridge next June.

At the meeting of the Senate on October 21 the degree of D.Sc. was granted to David Forsyth, of Guy's Hospital, as an internal student, for a thesis entitled "The Parathyroid Glands" ; to Samuel J. M. Auld, of East London College, as an internal student, for a thesis entitled "The Hydrolysis of Amygdalin by Emulsin "; to Henry Bassett, an external student, for a thesis entitled "Contributions to the Study of the Calcium Phosphates" ; and the degree of B.Sc. by research to Joseph Yates, Municipal Technical School, Blackburn, an external student, for research work in organic chemistry.

A university course of eight lectures on "Some Problems of General Physiology, more Particularly those Associated with Muscle," was commenced by Dr. F. S. Locke, in the physiology laboratory of the University, on October 20. A university course of three lectures by Mr. R. Lyddeker, F.R.S., on "The Living and Extinct Faunas of Africa and South America," commenced on October 28 at University College. A university course of eight lectures

NO. 2035, VOL. 78] 